\title{
PENENTUAN NILAI KESETIMBANGAN ADSORBSI ZAT WARNA ALAMI KULIT MAHONI KE DALAM KAIN DENGAN PROSES BATCH
}

\author{
Paryanto*, Muhammad Fadilah Arsyad, Muhammad Fardan Ibnu Aji \\ ${ }^{1}$ Program Studi Teknik Kimia Fakultas Teknik Universitas Sebelas Maret \\ Jl. Ir. Sutarmi 36A Jebres Surakarta 572126. \\ Email: paryanto.uns@gmail.com
}

\begin{abstract}
Abstrak
Adsorpsi adalah proses perpindahan massa pada permukaan pori-pori dalam butiran adsorben. Perpindahan massa yang terjadi melalui batas antara dua fasa dan adsorpsi merupakan proses eksotermis. Tujuan penelitian ini adalah memperoleh analisa data serta menentukan nilai kesetimbangan adsorbsi dari larutan zat warna alami mahoni ke kain dengan variasi konsentrasi zat warna alami sebesar 70\%, 50\%, 30\%, dan 10\% dalam suhu ruangan terhadap waktu pencelupan, lalu membandingkannya dengan metode Langmuir dan Freundlich. Zat warna yang telah diuji kadar taninnya ke dalam gelas ukur dan memasukkan kain sebagai media perpindahan massa tanin dari cairan ke padatan. Sampel diambil tiap 10 menit dan diuji kandungan taninnya dengan spektrofotometri (panjang gelombang $745 \mathrm{~nm}$ ) dan didapatkan harga Ca. Percobaan dihentikan ketika Ca sudah cenderung konstan yang menandakan perpindahan massa sudah setimbang. Percobaan diulangi pada variasi konsentrasi $70 \%, 50 \%, 30 \%$, dan 10\%. Hasil analisis penentuan adsorpsi kain terhadap zat warna alami yang paling sesuai adalah dengan menggunakan persamaan adsorpsi Freundlich dibandingkan dengan persamaan adsorpsi Langmuir. Hal ini dibuktikan dengan nilai kesalahan persamaan Freundlich lebih kecil dari persamaan Langmuir yang bisa dilihat dari nilai $\mathrm{R}^{2}$ yang mendekati angka 1 . Nilai $\mathrm{R}^{2}$ untuk persamaan Freundlich sebesar 0,9905 sedangkan untuk persamaan Langmuir sebesar 0,8963. Nilai konstanta Freundlich diperoleh sebesar $0,1122 \mathrm{~L} / \mathrm{gr}$ sedangkan nilai konstanta Langmuir diperoleh sebesar $0,0204 \mathrm{~L} / \mathrm{gr}$.
\end{abstract}

Kata kunci: adsorbsi, Freunlich, Langmuir, Mahoni, Tanin

\section{PENDAHULUAN}

Berkembangnya industri didalam negeri memberikan pengaruh positif berupa meningkatnya perekonomian nasional. Namun demikian, perkembangan industri ini membawa efek negatif yaitu menurunnya kualitas lingkungan akibat limbah yang dihasilkan dari kegiatan industri tersebut. Limbah industri baik berupa gas, cair maupun padat pada umumnya termasuk dalam kategori limbah B3 (bahan berbahaya dan beracun). Industri tekstil adalah salah satu jenis industri yang sedang berkembang pesat di Indonesia. Belakangan ini berkembang zat warna alami sebagai pewarna tekstil karena pewarna alami memiliki limbah yang tidak berbahaya dibandingkan dengan pewarna sintesis.

Mahoni merupakan salah satu bahan yang dapat dijadikan sebagai zat warna alami dalam proses membatik karena mahoni memiliki kandungan Pigmen Antosianin, Tanin, Klorofil, Flavonoid dan Karotenoid. Kandungan paling besar terdapat pada pigmen tanin dengan kadar sebesar $42,78 \%$ menghasilkan warna coklat, disusul oleh antosianin sebesar 7,17\% menghasilkan warna orange, selanjutnya ada flavonoid dengan kadar sebesar $0,71 \%$ menghasilkan warna merah maron, kemudian pada klorofil memiliki kadar sebesar $0,31 \%$ menghasilkan warna hijau tua, dan kadar pigmen terkecil terdapat pada karotenoid dengan kadar $0,18 \%$ menghasilkan warna merah (Rikman, 2016).

Tanin adalah pigmen tumbuhan dengan berat molekul tinggi antara $500-20.000$ (Schofield, 2001). Oleh sebab itu, Penelitian ini dimaksudkan untuk mendapatkan dan menganalisa data serta konstanta kesetimbangan adsorpsi antara larutan tanin kulit mahoni dengan kain tipis (slab), lalu membandingkan data kesetimbangan adsorpsi antara metode Langmuir dan Freundlich agar mendapatkan nilai kesetimbangan adsorbsi yang optimum.

\subsection{Pohon Mahoni}

Mahoni adalah tumbuhan tropis yang tumbuh liar di hutan jati, pinggir pantai dan di samping - samping jalan sebagai pohon 
peneduh. Zat - zat fotokimia pada kulit kayu mahoni yang berhasil diidentifikasi di antaranya alkaloid, flavonoid, saponin, tanin, tripenoid, swietemacrofilamin, katekin, dan epikatekin (Falah, 2008). Kandungan pigmen antosianin, tanin, klorofil, flavonoid dan karotenoid pada kulit kayu mahoni (Swietenia macrophylla) berturut-turut adalah $7,17 \% ; 42,78 \% ; 0,31 \%$ $; 0,71 \%$; dan $0,18 \%$ (Rikman, 2016). Di antara zat-zat kimia yang terkandung dalam kulit kayu mahoni ada zat yang dimanfaatkan sebagai zat warna alam yaitu tanin dan flavonoid (Meilani dan Putri, 2012).

\subsection{Tanin}

Tanin adalah senyawa kimia yang dihasilkan oleh kulit kayu dan buah tumbuhan, memiliki rumus kimia yang tergolong kompleks dan memiliki senyawa yang bervariasi serta dimanfaatkan sebagai penyamak, contohnya korilagin $\mathrm{C}_{27} \mathrm{H}_{24} \mathrm{O}_{18}$. Tanin dapat didefinisikan sebagai senyawa polifenol dengan berat molekul yang sangat besar yaitu lebih dari 1000 $\mathrm{g} / \mathrm{mol}$ serta dapat membentuk senyawa kompleks dengan protein.

Tanin memiliki sifat antara lain dapat larut dalam air atau alkohol karena tanin banyak mengandung fenol yang memiliki gugus $\mathrm{OH}$, dapat mengikat logam berat, serta adanya zat yang bersifat anti rayap dan jamur. Warna tanin akan menjadi gelap apabila terkena cahaya atau dibiarkan di udara terbuka. Tanin umumnya didapatkan dengan ekstraksi dari tanaman. Tujuan dari ekstraksi tanin adalah terdifusinya sejumlah gugus fenol yang terkandung dalam material tanaman menuju fase cair. Hasil ekstrak tanin yang terekstrak harus segera dianalisis kadarnya (Makkar, 2003).

\subsection{Adsorbsi}

Adsorbsi adalah proses perpindahan massa pada permukaan pori - pori dalam butiran adsorben. Perpindahan massa yang terjadi melalui batas antara dua fasa yaitu : gas padat, cair - padat. Adsorbsi merupakan proses eksotermis. Panas adsorbsi yang dihasilkan merupakan penurunan panas atau pelepasan energi dalam sistem.

Adsorbsi dapat terjadi karena adanya energi permukaan dan gaya tarik menarik permukaan. Sifat dari masing - masing permukaan berbeda, tergantung pada susunan dalam molekul molekul zat. Setiap molekul dalam interior dikelilingi oleh molekul - molekul lainnya, sehingga gaya tarik menarik antar molekul akan sama besar, setimbang ke segala bagian. Sedangkan untuk molekul dipermukaan hanya mempunyai gaya tarik kearah dalam (Asip dkk., 2008).

Kesetimbangan proses adsorbsi dipengaruhi oleh jenis adsorbate dan adsorbent, suhu dan konsentrasi adsorbate. Setiap adsorbate dan adsorbent mempunyai karakteristik kesetimbangan yang berbeda - beda dan kesetimbangan adsorbsi tidak dipengaruhi oleh ukuran adsorbent. Berdasarkan kekuatan interaksi atau gaya yang menyebabkan terjadinya proses adsorbsi, adsorbsi dibagi menjadi 2 jenis, yaitu:

\section{Physical Adsorption (Van der Waals} adsorption)

Physical adsorption merupakan adsorbsi yang terjadi karena gaya tarik-menarik antara zat yang teradsorbsi dengan padatan. Jika gaya tarik-menarik antara adsorbate dan adsorbent lebih besar dibandingkan sesama adsorbate, maka adsorbate akan terjerap di permukaan padatan. Adsorbsi fisika biasanya terjadi pada suhu dan tekanan rendah. Adsorbsi jenis ini lemah, gaya yang menyebabkan terjadinya adsorbsi adalah gaya Van der waals. Panas adsorbsi yang dihasilkan sekitar $5-10$ $\mathrm{kkal} / \mathrm{mol}$ Interaksi adsorbsi ini bersifat reversibel yang memungkinkan terjadinya desorpsi pada suhu yang sama, meskipun proses tersebut lambat karena adanya efek difusi (Treybal, 1981).

\section{Chemisorption}

Chemisorption merupakan adsorbsi yang terjadi karena adanya reaksi kimia antara padatan dengan adsorbate. Adsorbsi ini bersifat irreversibel dan panas yang dihasilkan cukup besar dibanding dengan adsorbsi fisika (Treybal, 1981). Adsorbsi kimia mencakup pembentukan ikatan kimia. Pada adsorbsi kimia ikatannya sedemikian kuat sehingga spesies aslinya tidak dapat ditemukan lagi. Bentuk lapisan pada adsorbsi kimia biasanya merupakan monolayer (Maghfiroh, 2016).

Jika penjerapan yang terjadi karena pengaruh gaya intermolekuler antara fluida dan padatan lebih besar dari molekul fluida itu sendiri maka molekul fluida akan terjerap (terakumulasi) di permukaan padatan hingga mencapai kondisi jenuh (Treybal, 1981). Dalam proses adsorbsi dua fase, kondisi suhu cukup berpengaruh dalam system tenaga adsorbsi. 
Pada temperatur normal, sebaiknya dilakukan dengan tenaga intermolekuler (Mardina, 2007). Adsorbsi akan lebih cepat berlangsung pada suhu tinggi. Akan tetapi, pengaruh suhu adsorbsi zat cair tidak sebesar pada adsorbsi gas.

Selain itu proses adsorbsi sangat sesuai untuk memisahkan bahan dengan konsentrasi yang rendah dari campuran yang mengandung bahan lain dengan konsentrasi tinggi. Pada fase cair, konsentrasi fase menunjukkan perubahan kuantitas unit volume dari cairan atau larutan. Pada stationary-phase atau fase padat maka harga konsentrasi fase merupakan perubahan kuantitas akibat transfer massa dari unit fase dalam kondisi tertentu. Hal ini memungkinkan konsentrasi bahan padat lebih rendah dibandingkan dengan konsentrasi bahan cair dan perbedaan konsentrasi bahan padat lebih rendah dibandingkan dengan konsentrasi bahan cair sehingga perbedaan konsentrasinya cukup besar atau driving force ini dapat menyebabkan konsentrasi profilnya lambat sedangkan proses transfer massanya berlangsung cepat (Mardina, 2007).

Pada proses adsorbsi terdapat 2 unsur penting, yaitu: mekanisme kesetimbangan dan kinetika. Mekanisme kesetimbangan didasarkan pada kapasitas padatan untuk menyimpan atau menjerap spesies (adsorbate) yang berbeda. Mekanisme kinetika didasarkan pada kecepatan penyebaran (difusi) spesies yang berbeda untuk masuk ke pori padatan. Adsorbat merupakan solut yang terserap pada permukaan padatan dalam proses adsorbsi. Faktor yang mempengaruhi banyaknya jumlah adsorbat yang dapat diserap oleh adsorben, antara lain: jenis adsorben, jenis adsorbat, ukuran adsorben, konsentrasi adsorbat, dan temperatur (Putranto dan Angelina, 2014).

\subsection{Kesetimbangan Adsorbsi}

Kesetimbangan bahan dalam fase cair dengan kadar bahan dalam fase padat umumnya dinyatakan dalam beberapa model, diantaranya model Langmuir dan model Freundlich.

1. Model Langmuir

Model Langmuir mengasumsikan bahwa adsorbsi lapisan tunggal (monolayer) pada permukaan yang mengandung sejumlah tertentu pusat adsorbsi dengan energi-energi adsorbsi yang seragam tanpa perpindahan adsorbat pada bidang permukaan (Hasrianti, 2012). Persamaan adsorbsi Langmuir dapat diturunkan secara teoritis dengan menganggap terjadinya kesetimbangan antara molekul - molekul zat yang diadsorbsi pada permukaan adsorben dengan molekul - molekul zat yang tidak teradsorbsi (Day dan Underwood, 2002). Dimana persamaan Langmuir ditulis sebagai berikut:

$$
\frac{m \cdot C}{X m}=\frac{1}{a}+\frac{b \cdot C}{a}
$$

Dengan membuat kurva m.C / Xm terhadap $\mathrm{C}$ akan diperoleh persamaan linear dengan intersep 1/a dan kemiringan (b/a), sehingga nilai a dan $b$ dapat dihitung, dari besar kecilnya nilai a dan $b$ menunjukkan daya adsorbsi (Mulyatna dkk., 2003).

\section{Model Freundlich}

Model ini didasarkan pada anggapan bahwa tidak hanya satu lapisan molekul adsorban saja yang terserap adsorban sehingga lapisan permukaan tidak terbatas. Setelah permukaan padatan menyerap suatu lapisan molekul adsorban, maka adsorben tersebut membentuk lapisan penyerap dan menyerap adsorban lain. Menurut Freundlich, jika y adalah berat zat terlarut per gram adsorben dan $\mathrm{c}$ adalah konsentrasi zat terlarut dalam larutan. Dari konsep tersebut dapat diturunkan persamaan sebagai berikut:

$$
\log \frac{X m}{m}=\log k+\frac{1}{n} \cdot \log C .
$$

Dengan $\mathrm{k}$ dan $\mathrm{n}$ adalah konstanta adsorbsi yang nilainya bergantung pada jenis adsorben dan suhu adsorbsi. Bila dibuat kurva $\log (\mathrm{Xm} /$ m) terhadap $\log \mathrm{C}$ akan diperoleh persamaan linear dengan intersep $\log \mathrm{k}$ dan kemiringan $1 / \mathrm{n}$, sehingga nilai $\mathrm{k}$ dan $\mathrm{n}$ dapat dihitung (Mulyatna dkk., 2003).

Penyerapan zat dari larutan mirip dengan penyerapan gas oleh zat padat. Penyerapan bersifat selektif, yang diserap hanyalah zat terlarut atau pelarut. Bila dalam larutan ada dua zat atau lebih, zat yang satu akan diserap lebih kuat dari zat yang lain. Zat - zat yang dapat menurunkan tegangan permukaan akan lebih kuat diserap. Semakin kompleks zat yang terlarut, maka semakin kuat diserap oleh adsorban. Semakin tinggi temperatur, maka semakin kecil daya serap. Namun demikian, pengaruh temperatur tidak sebesar pada temperatur gas.

\section{METODOLOGI}

\subsection{Bahan}

Bahan yang digunakan adalah serbuk kayu mahoni, kain, dan aquadest. 


\subsection{Alat}

Alat yang digunakan antara lain gelas ukur, dan spektrofotometer.

\subsection{Prosedur Penelitian}

Tahap pertama yaitu memasukkan zat warna ke dalam kuvet untuk menguji kadar tanin kulit kayu mahoni, diambil sampel ekstrak setelah proses ekstraksi sebanyak $5 \mathrm{ml}$ dengan cara spektrofotometri dan didapatkan data konsentrasi awal zat warna alami kulit kayu mahoni sebagai $\mathrm{C}_{\mathrm{Ao}}$. Tahap kedua dilakukan dengan cara memasukkan zat warna yang telah diuji kadar taninnya ke dalam gelas ukur 100 ml, kemudian memasukkan kain sebagai media perpindahan massa tanin dari cairan ke padatan. Sampel diambil tiap 10 menit dan diuji kandungan taninnya dengan spektrofotometri (panjang gelombang $745 \mathrm{~nm}$ ) dan didapatkan harga Ca. Percobaan dihentikan ketika $\mathrm{Ca}$ sudah cenderung konstan yang menandakan perpindahan massa sudah setimbang. Percobaan diulangi pada variasi konsentrasi $70 \%, 50 \%$, $30 \%$, dan $10 \%$.

\subsection{Analisa Hasil}

Setelah kadar tanin diketahui, selanjutnya adalah menentukan konstanta kesetimbangan adsorbsi dengan persamaan Langmuir dan Freundlich yang telah disusun, kemudian dilakukan perhitungan secara numeris menggunakan program excel. Data diambil dari hasil percobaan ekstraksi tanin dari kulit kayu mahoni (Switenia mahoni). Nilai konstanta kesetimbangan adsorbsi optimum dapat dicari dengan membandingkan hasil perhitungan antara persamaan Langmuir dan persamaan Freundlich pada variasi konsentrasi $70 \%, 50 \%$, $30 \%$, dan $10 \%$.

\section{HASIL DAN PEMBAHASAN}

3.1. Penentuan Kondisi Operasi Adsorpsi Zat Warna Serbuk Kayu Mahoni ke Dalam Kain

Proses perpindahan massa zat warna serbuk kayu mahoni dilakukan dengan mencelupkan kain pada zat warna tersebut dan dilakukan dengan berbagai variasi konsentrasi awal. Data yang diperoleh kemudian dibandingkan dengan data hasil perhitungan sehingga menghasilkan nilai kesetimbangan adsorbsi.

\section{(i) Data Konsentrasi $\mathbf{C}_{\mathrm{Ao}}$}

Tanin standar yang diperoleh di pasaran dibuat larutan standar dengan konsenstrasi antara $10-100$ ppm kemudian dicek adsorbansinya menggunakan spektrofotometri pada panjang gelombang $745 \mathrm{~nm}$. Hasil data yang diperoleh dari analisa kadar tanin standar kemudian dibuat grafik seperti terlihat pada gambar dibawah ini.

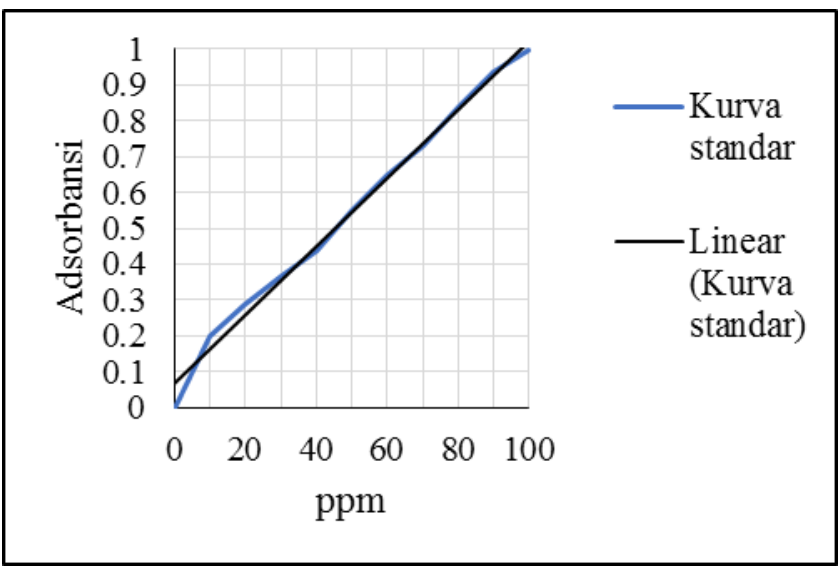

\section{Gambar 1. Grafik Hubungan antara Adsorbansi dan \\ Kadar Tanin Larutan Baku (Tanin Standar)}

Zat warna yang telah dihasilkan dianalisa kandungan taninnya dengan cara spektrofotometri dan diperoleh data adsorbansi sebesar 0,684; kemudian data adsorbansi dihubungkan dengan grafik larutan standar 
tanin diatas dan diperoleh data kandungan tanin yang ada pada zat warna sebesar 65,5 ppm.

\section{(ii) Variasi Konsentrasi Awal}

Larutan zat warna alami yang telah diketahui konsentrasinya kemudian diencerkan dengan air agar diperoleh beberapa konsentrasi.
Kain dengan berat 2,5 gram dimasukkan ke dalam gelas ukur yang sudah terisi 0,1 L larutan zat warna. Sampel diambil tiap 1 menit untuk dianalisa konsentrasinya hingga keadaan sudah setimbang.

Tabel 1. Jumlah Tanin yang Teradsorbsi oleh Kain pada Beberapa Konsentrasi Variasi

\begin{tabular}{ccccccc}
\hline No. Tanin awal & $\begin{array}{c}\text { Tanin } \\
\text { setimbang } \\
(\mathbf{p p m})\end{array}$ & $\begin{array}{c}\text { Tanin } \\
\text { teradsorbsi } \\
(\mathbf{p p m})\end{array}$ & $\begin{array}{c}\text { V larutan } \\
(\mathbf{L})\end{array}$ & $\begin{array}{c}\text { Massa } \\
\text { kain } \\
(\mathbf{g r})\end{array}$ & $\begin{array}{c}\mathbf{X m} / \mathbf{m} \\
(\mathbf{m g} / \mathbf{g r})\end{array}$ \\
\hline 6,7 & 5,8 & 0,9 & 0,1 & 2,5 & 0,036 \\
23,8 & 21,4 & 2,4 & 0,1 & 2,5 & 0,096 \\
33,4 & 30,8 & 2,6 & 0,1 & 2,5 & 0,104 \\
44,9 & 41,5 & 3,4 & 0,1 & 2,5 & 0,136 \\
65,5 & 61 & 4,5 & 0,1 & 2,5 & 0,180 \\
\hline
\end{tabular}

Tabel 1. menunjukkan bahwa semakin besar kandungan tanin yang ada pada zat warna maka semakin besar pula massa tanin yang teradsorpsi oleh kain. Di sisi lain, kemampuan kain untuk menyerap zat warna terbatas sehingga massa tanin yang teradsorpsi oleh kain tidak terlalu besar jika dibandingkan dengan semakin besarnya konsentrasi zat warna. Untuk konsentrasi 6,7 ppm dari 0,1 L larutan zat warna, massa tanin yang teradsorpsi adalah 0,9 mg oleh 2,5 gram kain, untuk konsentrasi 23,8 ppm sebesar 0,096 mg/gram, untuk konsentrasi 33,4 ppm sebesar 0,104 $\mathrm{mg} /$ gram dan konsentrasi 44,9 ppm sebesar 0,136 mg/gram kain. Massa terbesar dari massa tanin teradsorpsi oleh kain adalah pada konsentrasi $65,5 \mathrm{ppm}$ yaitu sebesar $0,18 \mathrm{mg} / \mathrm{gr}$. Hal ini sesuai dengan teori yang menyatakan bahwa apabila konsentrasi makin besar, maka jumlah solut yang teradsorpsi semakin besar (Widayatno et al, 2017).

\subsection{Penentuan Nilai Kesetimbangan Adsorbsi}

Pengujian pola isoterm adsorbsi yang sesuai untuk proses penyerapan tanin pada zat warna alami oleh kain dilakukan dengan perhitungan menggunakan persamaan Langmuir dan Freundlich.

\section{(i) Model Langmuir}

Model Langmuir didasarkan pada penyerapan satu lapisan, sehingga kapasitas permukaan untuk penyerapan ada nilai maksimumnya (terbatas).

Berdasarkan grafik yang telah dibuat, diperoleh persamaan $\mathrm{y}=3,266 \mathrm{x}+160,01$ dengan nilai $\mathrm{R}^{2}$ sebesar 0,8963 . Hal ini menunjukkan bahwa kesalahan dengan model ini tidak terlalu besar. Persamaan tersebut menjadi:

$$
\frac{m \cdot C e}{X m}=3,266 C e+160,01
$$

Berdasarkan persamaan diatas maka diperoleh nilai a sebesar $0,00625 \mathrm{mg} / \mathrm{gr}$ dan nilai $\mathrm{b}$ sebesar 0,0204 L/gr.

Tabel 2. Data - data untuk Persamaan Langmuir

\begin{tabular}{ccccc}
\hline No & $\begin{array}{c}\mathbf{C}_{\text {tanin awal }} \\
(\mathbf{p p m})\end{array}$ & $\mathbf{C e}(\mathbf{p p m})$ & $\begin{array}{c}\mathbf{X m} / \mathbf{m} \\
(\mathbf{m g} / \mathbf{g r})\end{array}$ & $\mathbf{C e} /(\mathbf{X m} / \mathbf{m})$ \\
\hline 6,7 & 5,8 & 0,036 & 161,11 \\
23,8 & 21,4 & 0,096 & 222,92 \\
33,4 & 30,8 & 0,104 & 296,15 \\
44,9 & 41,5 & 0,136 & 305,15 \\
65,5 & 61 & 0,180 & 338,89 \\
\hline
\end{tabular}




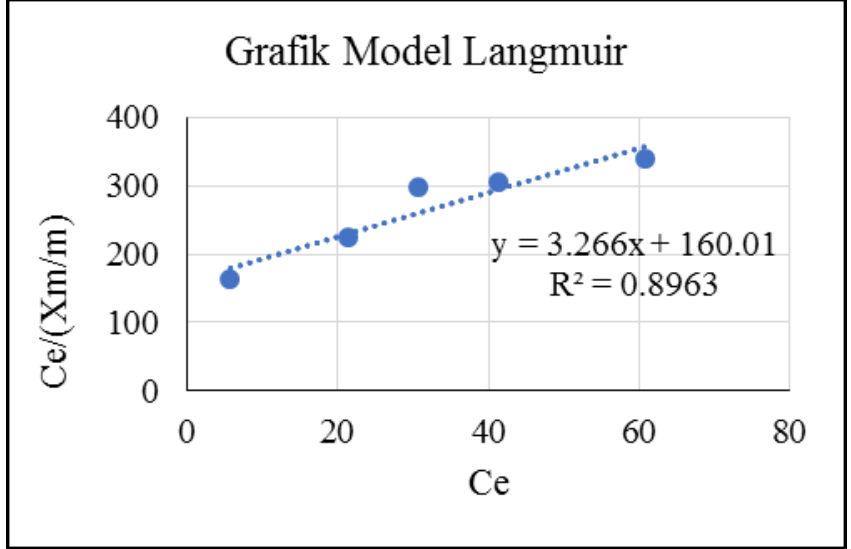

Gambar 2. Grafik Hubungan antara $\mathrm{Ce} /(\mathrm{Xm} / \mathrm{m})$ dengan $\mathrm{Ce}$

(ii) Model Freundlich

Model ini digunakan dan disarankan pada anggapan bahwa tidak hanya satu lapisan molekul adsorbat saja yang terserap padatan, sehingga lapisan molekul pada padatan tidak terbatas. Setelah permukaan padatan menyerap satu lapisan molekul adsorbat, maka padatan tersebut membentuk lapisan penyerapan baru dan menyerap adsorbat lainnya.

Tabel 3. Data - data untuk Persamaan Freundlich

\begin{tabular}{rccccc}
\hline No & $\begin{array}{c}\mathbf{C}_{\text {tanin awal }} \\
(\mathbf{p p m})\end{array}$ & $\mathbf{C e}(\mathbf{p p m})$ & $\begin{array}{c}\mathbf{X m} / \mathbf{m} \\
(\mathbf{m g} / \mathbf{g r})\end{array}$ & $\mathbf{L o g}(\mathbf{X m} / \mathbf{m})$ & $\log \mathbf{C e}$ \\
\hline 6,7 & 5,8 & 0,036 & $-1,44$ & 0,76 \\
& 23,8 & 3,4 & 0,096 & $-1,02$ & 1,33 \\
33,4 & 30,8 & 0,104 & $-0,98$ & 1,49 \\
44,9 & 41,5 & 0,136 & $-0,87$ & 1,62 \\
65,5 & 61 & 0,180 & $-0,74$ & 1,79 \\
\hline
\end{tabular}

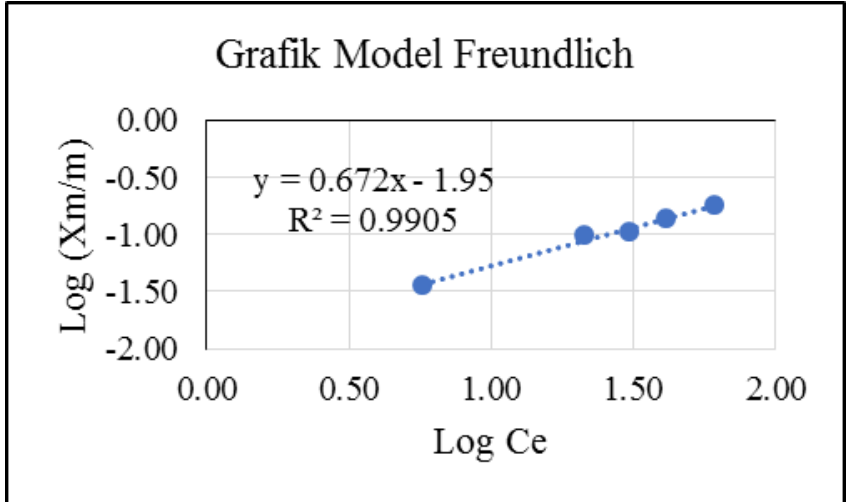

Gambar 3. Grafik Hubungan antara $\log (\mathrm{Xm} / \mathrm{m})$ dengan $\log C e$

Berdasarkan grafik yang telah dibuat, diperoleh persamaan $\mathrm{y}=0,672 \mathrm{x}-1,95$ dengan nilai $R^{2}$ sebesar 0,9905 . Hal ini menunjukkan bahwa kesalahan dengan model ini terbilang sangat kecil. Persamaan tersebut menjadi:

$$
\log \frac{X m}{m}=0,672 \log C_{e}-1,95
$$

Berdasarkan persamaan diatas maka diperoleh nilai $\mathrm{n}$ sebesar 1,488 dan nilai $\mathrm{k}$ sebesar 0,1122 $\mathrm{L} / \mathrm{gr}$.

\section{KESIMPULAN}

Penentuan kapasitas adsorpsi kain terhadap zat warna alami yang paling sesuai adalah dengan menggunakan persamaan adsorpsi Freundlich dibandingkan dengan persamaan adsorpsi Langmuir. Hal ini dibuktikan dengan nilai kesalahan persamaan Freundlich lebih kecil dari persamaan Langmuir 
yang bisa dilihat dari nilai $\mathrm{R}^{2}$ yang mendekati angka 1 . Nilai $\mathbf{R}^{2}$ untuk persamaan Freundlich sebesar 0,9905 sedangkan untuk persamaan Langmuir sebesar 0,8963. Nilai konstanta Freundlich diperoleh sebesar 0,1122 L/gr sedangkan nilai konstanta Langmuir diperoleh sebesar 0,0204 L/gr.

\section{DAFTAR PUSTAKA}

Asip, F., Mardhiah, R., Husna., (2008), Uji Efektifitas Cangkang Telur dalam Mengadsorbsi Ion $\mathrm{Fe}$ dengan Proses Batch, Palembang: Jurusan Teknik Kimia Fakultas Teknik Universitas Sriwijaya.

Day, R. A. and A. L. Underwood., (2002). Analisis Kimia Kuantitatif, Jakarta : Erlangga.

Falah, S., Suzuki, T. and Katayama, T., (2008), Chemical Constituents from Swietenia Macrophylla Bark and Their Antioxidant Activity, Pak J Biol Sci 11 : 2007 - 2012.

Hasrianti., (2012), Adsorpsi Ion Cd2+ dan Cr6+ Pada Limbah Cair Menggunakan Kulit Singkong, Makassar: Program Pasca Sarjana, Universitas Hasanuddin.

Maghfiroh, Lu'lu'atul., (2016), Adsorpsi Zat Warna Tekstil Remazol Brilliant Blue Menggunakan Zeolit yang Disintesis dari Abu Layang Batubara. Semarang: Universitas Negeri Semarang.

Makkar, S. dan Ahadi., (2003), Kandungan Tanin Terkondensasi dan Laju Dekomposisi pada Serasah Daun Rhizophora Mucronala Lamk pada Ekosistem Tambak Tum Pang Sari Di Blanakan, Purwakarta, Jawa Barat, Bogor : Institut Pertanian Bogor.

Mardina, P., (2007), Menentukan Koefisien Transfer Massa dan Diffusivitas Efektif dari Proses Dekolorisasi Zat Warna, Banjarmasin : Fakultas Teknik Universitas Lambung Mangkurat Banjarmasin.

Meilani, dan Putri, M., (2012), Pengambilan Zat Warna Alami dari Kulit Kayu Mahoni (Swietenia Mahagoni (L.) Jacq), Surakarta : Jurusan Teknik Kimia Fakultas Teknik Universitas Sebelas Maret Surakarta.

Mulyatna, L., Pradiko, H. dan Nasution, K., (2003), Pemilihan Persamaan Adsorpsi Isotherm pada Penentuan Kapasitas Adsorpsi Kulit Kacang Tanah terhadap Zat Warna Remazol Golden Yellow 6,
Bandung: Teknik Lingkungan, Fakultas Teknik Universitas Pasundan.

Putranto, A. dan Angelina, S., (2014), Pemodelan Perpindahan Massa Adsorpsi Zat Warna pada Florisil dan Silica Gel dengan Homogeneous and Heterogeneous Surface Diffusion Model. Bandung : Lembaga Penelitian dan Pengabdian kepada Masyarakat Universitas Katolik Parahyangan Bandung.

Rikman., (2016), Kandungan Pigmen Antosianin, Tanin, Klorofil, Flavonoid dan Karotenoid pada Kulit Kayu Mahoni (Swietenia macrophylla) sebagai Bahan Dasar Pewarna Alami. Sulawesi Tenggara : Universitas Haluoleo.

Schofield, P., Mbugua, D.M. and Pell, A.N., (2001), Analysis of Condensed Tannins, a Review, Animal Feed Science and Technology. 91. pp. 21-40.

Treybal, R. E., (1981), Mass-Transfer Operation. $3^{\text {rd }}$ edition. Japan : McGraw Hill Book Co. Inc.

Widayatno, T., Yuliawati, T., Susilo, A.A., (2017), Adsorpsi Logam Berat (Pb) dari Limbah Cair dengan Adsorben Arang Bambu Aktif. Surakarta: Program Studi Teknik Kimia, Fakultas Teknik Universitas Muhammadiyah Surakarta. 